\title{
Investigating Maar Formation and the Climate History of Southern Argentina-the Potrok Aike Maar Lake Sediment Archive Drilling Project (PASADO)
}

\author{
by Bernd Zolitschka, Hugo Corbella, Nora Maidana, and Christian Ohlendorf
}

doi:10.2204/iodp.sd.3.13.2006

Evidence is increasing that the Southern Ocean plays a key role in the global climate system. The southern hemisphere contains more than $90 \%$ of the world's ice, and eighty-one percent of its total surface area is covered by oceans. On global terms, the most extreme oceanic character is encountered between $40^{\circ} \mathrm{S}$ and $60^{\circ} \mathrm{S}$ latitude, where land (Patagonia and a few islands) comprises only $2 \%$ of the surface area. Terrestrial archives of past climate changes are thus extremely scarce at these latitudes. As Patagonia is subject to shifts in polar and mid-latitude winds, pressure fields, and precipitation regimes, as well as to variations related to the El Niño Southern Oscillation (ENSO) and the Antarctic Oscillation (AO), it has the unique potential to record variations in the hydrological cycle, changes in aeolian dust deposition, the frequency of volcanic activity, and other natural forces that control climatic conditions. Lake sediments can provide important archives for such terrestrial climatic and environmental reconstructions. In the semi-arid steppe region of Patagonia, however, most of the lakes are periodically dry or ephemeral. One exception is the 100-m-deep crater lake Laguna Potrok Aike (Fig. 1), a $770 \pm 220$ thousand year old maar situated in the province of Santa Cruz, Argentina. The lake is located in the Pali Aike Volcanic Field (Fig. 2), the southernmost back-arc Neozoic volcanic field of South America. As Laguna Potrok Aike has not been reached by any Pleistocene ice advance during the last $1 \mathrm{Ma}$, it is potentially the only mid-latitude lake in the Southern Hemisphere with a continuous sedimentary record covering several glacial to interglacial cycles. In addition to global reconstructions, regional climatic variations represent other important aspects of research.

Seismic surveys and multidisciplinary reconstructions based on 1-m gravity and 19-m piston cores at Laguna Potrok Aike form the basis for the Potrok Aike Maar Lake Sediment
Archive Drilling Project (PASADO) to be developed within the framework of the International Continental Scientific Drilling Program (ICDP). Data from four seismic surveys demonstrate that the lake sediments exceed $150 \mathrm{~m}$ in thickness and overlie several hundred meters of volcanic breccias. These data clearly make Laguna Potrok Aike a well-suited site for terrestrial climate reconstructions of the Southern Hemisphere. In addition, they enable investigations about the formation of phreatomagmatic craters which have never been studied before by coring into a relatively young, mid-Pleistocene maar structure.

The recent PASADO workshop (Rio Gallegos, Argentina, 15-19 March 2006) discussed the scientific goals and implementation plan for drilling deep into the lakebed with the Global Lake Drilling Facility (GLAD 800) system. Fifty-two participants from five continents, eleven countries, and a wide spectrum of disciplines participated in the meeting. The scientific program started with a series of twenty-one talks on the regional background and limnogeological results from Laguna Potrok Aike. The workshop included a field trip to the Instituto Nacional de Tecnologia Agropecuaria (INTA) field station at Potrok Aike (Fig. 1) to introduce the potential drilling sites. The participants formed three groups focusing on (a) technical and logistical issues related to the GLAD 800 deep drilling, (b) volcanic evidence, and (c) records of environmental change.

The workshop continued with twenty-five additional talks subdivided into eight topical sessions. The first session focused on the ICDP with regard to funding and support, technical aspects of using the GLAD 800 system, and firsthand experiences of the Petén-Itzá Drilling Project (see report in this issue on page 25). The operations of this ICDP lake-drilling project were accomplished only a few days

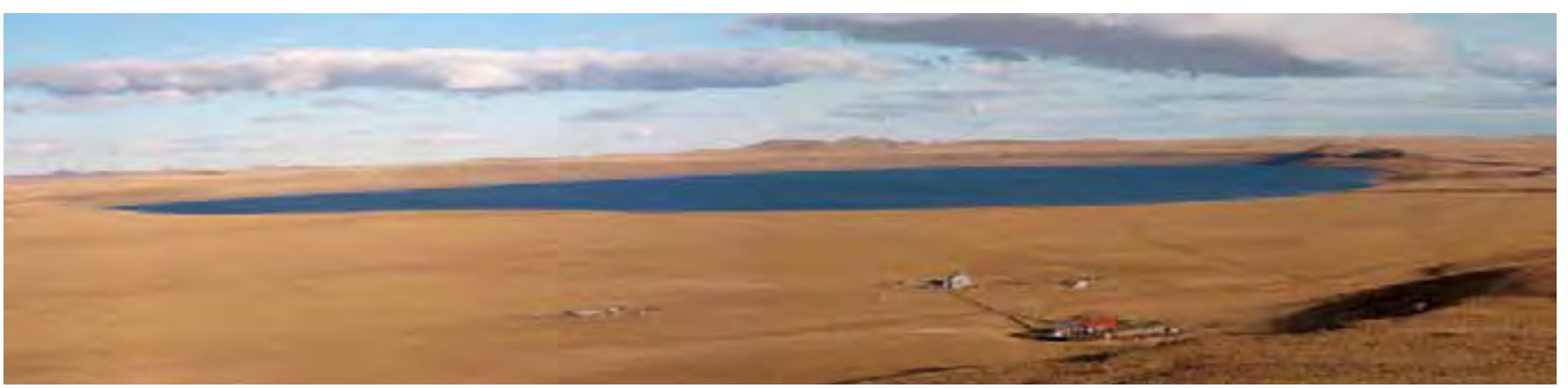

Figure 1. Overview of Laguna Potrok Aike from prominent basalt escarpment. This $770 \pm 220 \mathrm{ka}$ old maar lake is located at approximately $52^{\circ} \mathrm{S}, 70^{\circ} \mathrm{W}$ in Santa Cruz province, southern Patagonia (Argentina). Lake elevation $=113 \mathrm{~m}$, depth $=100 \mathrm{~m}$, and diameter $=3.5 \mathrm{~km}$. 


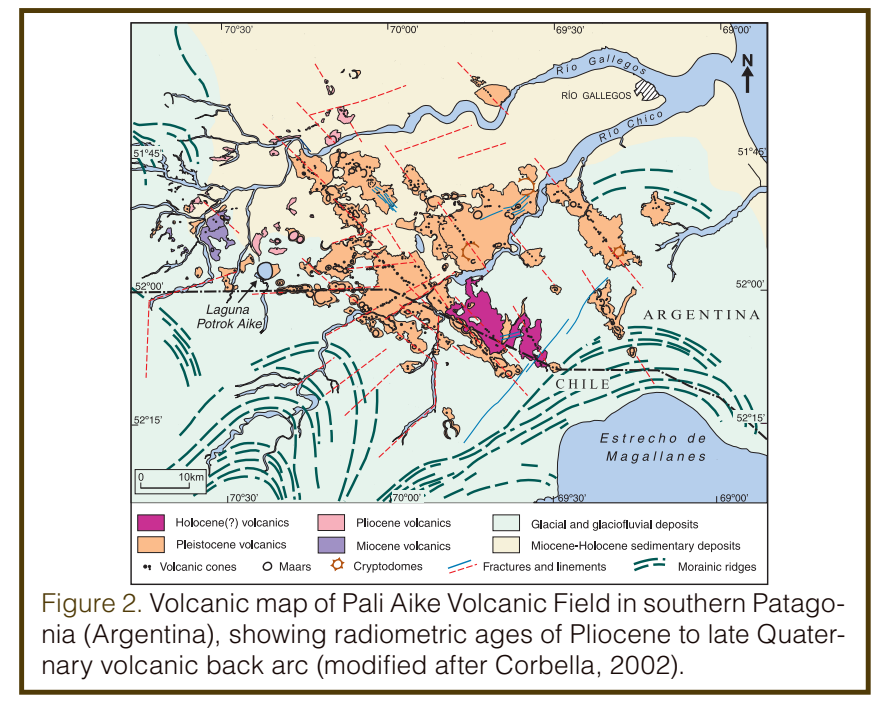

before the PASADO workshop started. The next session on understanding the evolution of maar volcanoes emphasized the importance of drilling into young maar structures for a better understanding of phreatomagmatic eruptions of such craters, and a subsequent session on the history of volcanic eruptions and tephrochronology established the study of volcanic ash layers as an important tool for inter-site and inter-archive correlation as well as for improving the time control of sedimentary records. The fourth session on deciphering high-frequency environmental variations introduced methods for downhole logging and non-destructive analysis of sediment cores that potentially provide ultra-high resolution data of environmental variations, whereas the fifth session on reconstruction of the Earth's magnetic field and rock magnetics demonstrated the possibilities of establishing a paleosecular variation record that might serve as another tool for stratigraphic correlation and of rock magnetics as a means to develop a magnetic proxy for climate change. The largest session on reconstruction of lacustrine and catchment-related environmental conditions focused on pollen, diatoms, chironomids, non-siliceous algae, and charcoal as paleobiological indicators for quantitative climate and environmental reconstruction. A subsequent session on tracing atmospheric dust and volcanic aerosols considered monitoring approaches and isotopic analyses of aerosols, and the final session on human impact and modeling focused on archaeological issues related to the Pali Aike Volcanic Field and to modeling of sedimentation processes within the lake.

On the last day, the participants discussed, in the context of testable hypotheses the technical aspects of scientific drilling, including potential drilling sites, appropriate target depths, and the volcanological, inorganic, and organic aspects of core analysis.

Altogether, the PASADO workshop addressed several issues related to Earth history and climate, natural hazards, and volcanic systems during past glacial to interglacial cycles. Specific topics included quantitative climatic and environmental reconstruction, paleosecular variation of the Earth's magnetic field, fire history, frequency of volcanic activity and tephra fallout, dust deposition, evolution of phreatomagmatic maar craters, and the history of regional vol-canic activity. It was concluded that dust and tephra records might provide important links between this terrestrial record and marine sediment archives and ice cores from Antarctica, enabling the resulting reconstruction of climate variability to be compared statistically with global circulation model (GCM) simulations of this region.

The scientific program with a list of participants, the abstracts of scientific presentations, and the excursion guide have been published as special issue of Terra Nostra (Zolitschka, 2006). Further information about PASADO and how to join this international effort can be obtained from http://www.salsa.uni-bremen.de.

\section{Acknowledgements}

The PASADO workshop was organized by the team of GEOPOLAR (Institute of Geography, University of Bremen, Germany) and hosted by the Universidad Nacional de la Patagonia Austral (Río Gallegos, Argentina). This workshop was supported logistically by the Government of Santa Cruz and by the INTA, while the major financial support came from the International Continental Scientific Drilling Program (ICDP).

\section{References}

Corbella, H. 2002. El campo volcano-tectónico de Pali Aike. In Haller, M. (Ed.), Geología y Recursos Naturales de Santa Cruz: Buenos Aires (Asociación Geológica Argentina), 285-302.

Zolitschka, B., 2006. ICDP Workshop: Potrok Aike Lake Sediment Archive and Drilling Project (PASADO) - Program, Abstracts, Excursion Guide. Terra Nostra 1/2006:1-88.

\section{Authors}

Bernd Zolitschka, Geomorphology and Polar Research (GEOPOLAR), Institute of Geography, FB 8, University of Bremen, Celsiusstr. FVG-M, D-28359 Bremen, Germany, e-mail: zoli@uni-bremen.de

Hugo Corbella, Universidad Nacional de la Patagonia Austral, Rio Gallegos and Museo Argentino de Ciencias Naturales, Buenos Aires, Arroyo 897, Buenos Aires C1007AAA, Argentina.

Nora Maidana, Departamento de Biodiversidad y Biología Experimental, Universidad Nacional de Buenos Aires, Ciudad Universitaria, 1428 Buenos Aires, Argentina.

Christian Ohlendorf, Geomorphology and Polar Research (GEOPOLAR), Institute of Geography, FB 8, University of Bremen, Celsiusstr. FVG-M, D-28359 Bremen, Germany.

\section{Related Web Link}

http://www.salsa.uni-bremen.de 